JURNAL SYNTAX FUSION

Vol 1 No 12, Desember 2021

E-ISSN: 2775-6440 | P-ISSN: 2808-7208

Jurnal Homepage https://fusion.rifainstitute.com

\title{
PENGARUH PENAMBAHAN CORE STABILITY EXERCISE TERHADAP PENINGKATAN KEBUGARAN JASMANI A (DAYA TAHAN) PADA PRAJURIT MILITER BRIGIF 15 KUJANG II CIMAHI
}

\author{
Feny Oktaviyani $^{1)}$, Jenal Arifin ${ }^{2)}$ \\ 1) Universitas Negeri Sebelas Maret, Jakarta, Indonesia \\ ${ }^{2)}$ Jurusan Fisioterapi Poltekkes Kemenkes Jakarta III, Indonesia \\ Email: fenyokta89@gmail.com
}

\begin{abstract}
Abstrak
Kebugaran jasmani merupakan kemampuan tubuh dalam menjalankan aktivitas fisik tanpa menimbulkan keletihan secara berlebihan. Bagi seorang prajurit militer, kebugaran jasmani sangat berperan penting dalam meningkatan dan memeliharaan jasmani militer, guna mendukung pelaksanaan tugas pokok prajurit militer. Kebugaran jasmani dapat dioptimalkan salah satunya dengan core stability excercise. Penelitian ini bertujuan untuk menganalisis pengaruh penambahan core stability exercise terhadap peningkatan kebugaran jasmani A (daya tahan) pada prajurit militer di Brigif 15 Kujang II Cimahi. Penelitian quasi experiment dengan pendekatan pre-post two group design terdiri dari kelompok eksperimen dan kelompok kontrol. Dengan teknik purposive sampling dipilih sebanyak 48 orang yang terbagi menjadi dua kelompok yaitu kelompok eksperimen $(n=24)$ dan kelompok kontrol $(n=24)$. Kelompok eksperimen diberikan program latihan lari 12 menit dan core stability excercise sedangkan kelompok kontrol hanya diberikan latihan lari 12 menit dan pengumpulan data berupa test lari 12 menit. Terdapat perbedaan Mean skor kesegaran jasmani A antara kelompok eksperimen (Mean= 40.33; $\mathrm{SD}=3.54$ ) dan kelompok kontrol (Mean= 44.17; $\mathrm{SD}=6.72$ ) sebelum intervensi, dan perbedaan tersebut secara statistik signifikan $(\mathrm{p}=0.017)$. Terdapat perbedaan selisih skor kesegaran jasmani sebelum dan sesudah intervensi antara kelompok eksperimen (Mean= 4.38; $\mathrm{SD}=1.41)$ dan kelompok kontrol (Mean= 2,42; $\mathrm{SD}=2.04)$ dan secara statistik signifikan $(\mathrm{p}<0.001)$, dengan effect size $=1.14$. Latihan core stability efektif untuk meningkatkan nilai kesegaran jasmani A pada prajurit Brigif 15 Kujang II Cimahi.
\end{abstract}

Kata Kunci: Kebugaran jasmani, Core stability exercise, Lari 12 menit

\section{Abstract}

Physical fitness is the body's ability to carry out physical activities without causing excessive fatigue. For a military soldier, physical fitness plays an important role in improving and maintaining the military body, in order to support the implementation of the main tasks of military soldiers. Physical fitness can be optimized, one of which is the core stability exercise. This study aims to analyze the effect of adding core stability exercise to increase physical 
fitness A (endurance) in military soldiers at Brigif 15 Kujang II Cimahi. A quasiexperimental study with a pre-post two group design approach consisting of an experimental group and a control group. With purposive sampling technique, 48 people were selected which were divided into two groups, namely the experimental group $(n=24)$ and the control group $(n=24)$. The experimental group was given a 12-minute running exercise program and core stability exercise while the control group was only given a 12-minute running exercise and data collection in the form of a 12-minute running test. There was a difference in the mean physical fitness score A between the experimental group $($ Mean $=40.33 ; S D=3.54)$ and the control group (Mean= 44.17; $S D=6.72)$ before the intervention, and the difference was statistically significant ( $p=$ 0.017). There was a difference in physical fitness scores before and after the intervention between the experimental group (Mean $=4.38 ; S D=1.41)$ and the control group $($ Mean $=2.42 ; S D=2.04)$ and statistically significant $(p<0.001)$, with effect size $=1.14$. Core stability exercise is effective to increase the value of physical fitness A in Brigif 15 Kujang II Cimahi soldiers.

Keywords: Physical fitness, Core stability exercise, Running 12 minutes

Diterima: 16-11-2021

Direvisi: $15-12-2021$

Diterbitkan: 20-12-2021

\section{Pendahuluan}

Prajurit adalah warga negara yang dipersiapkan dan dipersenjatai untuk tugastugas pertahanan negara guna menghadapi ancaman militer maupun ancaman bencana. Dalam Undang-Undang Republik Indonesia No. 34 Tahun 2004 disebutkan bahwa Tentara Nasional Indonesia (TNI) sebagai alat pertahanan Negara Kesatan Republik Indonesia (NKRI) bertugas menegakkan kedaulatan negara, mempertahankan keutuhan wilayah, melindungi keselamatan bangsa, dan menjalankan operasi militer untuk perang maupun selain perang (Indonesia, 2004).

Tugas militer tidak lepas dari aktivitas fisik yang berat. Menurut Subagyo Irianto (2012), unsur utama keberhasilan tugas TNI AD adalah kemampuan kebugaran jasmani yang prima karena dalam melaksanakan tugasnya dihadapkan pada kondisi alam Indonesia yang bervariasi seperti bukit, pegunungan, lembah, rawa, dan hutan tropis. Oleh sebab itu, seorang prajurit yang telah menjadi anggota TNI maupun siswa prajurit yang sedang menjalani pendidikan pertama harus memiliki kebugaran jasmani yang baik agar dapat melaksanakan tugas dan fungsi pokoknya secara optimal (Perwira et al).

Kebugaran jasmani adalah kemampuan tubuh dalam menjalankan aktivitas fisik tanpa menimbulkan keletihan secara berlebihan. Kebugaran jasmani pada diri seseorang sangat dipengaruh oleh kondisi kegiatan fisik yang dilakukan. Kondisi fisik sangat penting dan faktor penting bagi seseorang untuk melakukan kegiatan sehari hari. Sehingga kebugaran jasmani baik akan memberikan dampak dalam menjalankan kegiatan menjadi lebih segar dan tidak cepat lelah (Sinuraya \& Barus, 2020). 
Komponen kebugaran jasmani secara fisiologis adalah fungsi dasar dari komponen-komponen anatomis tersebut di atas, yaitu fungsi dasar yang wujudnya adalah kekuatan (strength), daya Tahan (endurance), daya otot (muscular power), kecepatan (speed), daya lentur (flexibility), kelincahan (agility), koordinasi (coordination), keseimbangan (balance), ketepatan (accuracy), reaksi (reaction) (Penjakora et al., 2021).

Sejak awal munculnya Covid-19, insidensi penularan virus semakin meningkat bahkan penyebarannya yang sangat cepat. Dikarenakan penyebaran yang sangat cepat dan belum ditemukannya vaksin, maka prajurit disarankan untuk mengurangi aktivitas di luar asrama. Penerapan physical distancing ini menyebabkan aktivitas fisik yang dapat dilakukan untuk kesehatan seperti olahraga menurun. Hal ini menyebabkan kebugaran jasmani (daya tahan) pada prajurit menurun (Nugraha et al., 2020).

Daya tahan yang baik sangat menunjang kinerja militer, termasuk daya tahan kardiorespirasi dan daya tahan otot. Daya tahan kardiorespirasi yang dinyatakan dengan $\mathrm{VO}_{2}$ Max adalah kesanggupan jantung, paru, dan pembuluh darah untuk berfungsi secara optimal pada keadaan istirahat dan latihan untuk mengambil oksigen dan mendistribusikan ke jaringan yang aktif untuk metabolisme tubuh. Daya tahan otot juga diperlukan untuk menghindari kelelahan yang berlebihan. Daya tahan otot adalah kemampuan otot atau sekelompok otot rangka untuk meneruskan konstraksi pada jangka waktu yang lama, serta kemampuan pemulihan yang cepat setelah lelah (Teofa, 2019).

Daya tahan sangat penting bagi prajurit, dengan daya tahan yang baik dapat menunjang prajurit dalam melakukan kegiatan. Salah satu bentuk latihan untuk meningkatkan daya tahan otot adalah dengan latihan core stability exercise. Core stability exercise adalah teknik strengthening dengan gerakan kontraksi untuk meningkatkan fungsi otot-otot yang diyakini mengatur stabilitas trunk dan ketika otototot yang berfungsi secara optimal, mereka akan melindungi tulang belakang dari trauma. Core stability exercise bertujuan untuk melatih pola motorik otot, melancarkan aliran darah, meningkatkan metabolisme tubuh, meningkatkan stabilitas tulang belakang, mengurangi nyeri, memperbaiki postur, keseimbangan, kelincahan dan meningkatkan fleksibilitas punggung bawah (Coulombe et al., 2017).

Menurut Johnson, 2012 core stability merupakan kemampuan mengontrol posisi tubuh dan gerakan sentral tubuh yang menargetkan otot - otot dan persendian dalam perut serta terhubung ke tulang belakang atau lumbopelvic, bahu, dan panggul. Sudah jelas bahwa Core stability static berkontraksi pada postur tubuh dan memberikan dasar gerakan pada semua bagian lengan dan kaki. menurut Akuthota (2008) dalam literature kedokteran bahwasannya core stability meningkatkan produk kontrol motorik dan kapasitas otot pada lumbo-pelvi-hip complex' untuk pencegahan cedera saat melakukan kinerja dan digunakan latihan terapi untuk kondisi nyeri pada pengkondisian tubuh. Sepemahaman juga dengan Demiral, 2019. Core stability dimaksud juga untuk meningkatkan kontrol neuromuskular, dan daya tahan dari trunk muscles yang mengharuskan menjaga stabilitas pada tulang belakang. Core stability memungkinkan 
akan meningkatkan stabilitas pada batang tubung bagian ekstremitas atas dan dapat beradaptasi dengan pemulihan cedera pada atlet saat melakukan aktifitas intensitas tinggi (Miyake, 2013).

Berdasarkan uraian diatas penulis tertarik untuk mengoptimalkan kebugaran jasmani militer dengan core stability exercise, maka penulis mengangkat topik ini dengan bentuk penelitian yang dituangkan dalam bentuk skripsi dengan judul "Pengaruh Penambahan Core Stability Exercise Terhadap Peningkatan Kebugaran Jasmani A(Daya Tahan) Pada Prajurit Militer Brigif 15 Kujang II Cimahi”.

\section{Metode Penelitian}

Penelitian ini merupakan penelitian kuantitatif jenis eksperimental, dengan desain penelitian quasi experimental dengan 1 kelompok eksperimen dan 1 kelompok pembanding. Pada penelitian ini dilakukan pemeriksaan terhadap kebugaran jasmani (daya tahan) sebelum (pre test) dan sesudah (post test) (Jasmani et al., n.d.). Diukur dengan menggunakan penilaian tes garjas "A" prajurit pria TNI AD. Kelompok eksperimen diberikan program latihan lari 12 menit dan core stability exercise, sedangkan kelompok pembanding hanya diberikan program latihan lari 12 menit.

Penelitian ini dilakukan di lapangan Brigif 15 kujang II Cimahi pada bulan maret sampai dengan bulan mei 2021. Jumlah responden 48 orang. Terdapat dua variabel dalam penelitian ini yaitu variabel independent adalah lari 12 menit dengan pembahan core stabillity exercise sedangkan variabel dependent adalah lari 12 menit.

Data penelitian ini didapatkan dan dikumpulkan dengan wawancara, pengisian informed concent, pengukuran tinggi badan, berat badan dan pemeriksaan vital sign.

Penelitian ini mengunakan purposive sampling dan sasaran responden adalah prajurit militer Brigif 15 Kujang II yang mengalami penurunan nilai kebugaran jasmani. Responden harus memenuhi syarat masuk kedalam kriteria inklusi berupa: Hasil pemeriksaan tekanan darah tidak boleh lebih dari 140/90 $\mathrm{mmHg}$, kondisi tubuh dalam keadaan sehat jasmani dan rohani, usia antara 18-30 tahun, jenis kelamin laki-laki, berat badan 60-70 kg, tinggi badan $165-172 \mathrm{~cm}$, Suhu tubuh $38^{\circ} \mathrm{C}$, Saat pemeriksaan responden wajib menggunakan masker saat pemeriksaan sebelum latihan dan kriteria eklusi berupa: Responden yang memiliki tensi darah lebih dari 140/90 $\mathrm{mmHg}$, denyut nadi lebih dari 100 kali per menit, berat badan lebih dari $70 \mathrm{~kg}$, suhu tubuh lebih dari $38^{\circ} \mathrm{C}$ dan tidak menggunakan masker saat pemeriksaan sebelum latihan.

Kemudian peneliti mendapatkan sampel sebanyak 48 responden dan dibagi menjadi dua kelompok yang masing-masing kelompok terdapat 24 responden. Sebelum melakukan pemeriksaan, peneliti memberikan inform consent dan tes lari 12 menit untuk mengetahui perbedaan sebelum dan sesudah diberikan intervensi selama 6 minggu sebanyak 3 kali dalam 1 minggu.

Penelitian ini telah mendapatkan persetujuan etik dari Komisi Etik Poltekkes Kemenkes Jakarta III dengan nomor surat KEPK-PKJ3/029/VI/2021. Berikut beberapa etik penelitian yang harus diperhatikan yaitu Informed consent, Anomity, Confidentiality, Safety (Protokol kesehatan). 


\section{Hasil dan Pembahasan}

\section{Hasil Analisis Data}

\section{a. Analisis Univariat}

Sebelum dilakukan analisis dan pembahasan hasil pengujian penelitian, akan dijelaskan gambaran karakteristik umum responden. Berikut data yang dapat disajikan:

Tabel 1 Karakteristik Sampel Berdasarkan Umur Pada Kelompok Eksperimen

\begin{tabular}{|c|c|c|}
\hline Usia & Frekuensi & Persentase (\%) \\
\hline 18-25 tahun & 12 & 50 \\
\hline 26-30 tahun & 12 & 50 \\
\hline Jumlah & 24 & 100 \\
\hline Mean & \multicolumn{2}{|c|}{25,7} \\
\hline Min & \multicolumn{2}{|c|}{19} \\
\hline Max & \multicolumn{2}{|c|}{30} \\
\hline CI $95 \%$ & \multicolumn{2}{|c|}{$24,4-27,1$} \\
\hline
\end{tabular}

Kelompok eksperimen yaitu responden diberikan lari 12 menit ditambah core stability exercise dengan program latihan rutin selama 6 minggu baik pada umur 18-25 tahun maupun 26-30 tahun masing-masing berbagi jumlah yang sama yaitu 12 orang (50\%). Nilai rerata umur sampel adalah 25,7 tahun, umur termuda 19 tahun umur tertua yaitu 30 tahun. Dari hasil estimate interval dapat disimpulkan bahwa 95\% diyakini bahwa rerata rentang umur prajurit yaitu 24,4-27,1 tahun.

Karakteristik sampel berdasarkan umur pada kelompok kontrol pada tabel 2 di bawah ini

Tabel 2 Karakteristik Sampel Berdasarkan Umur Pada Kelompok Kontrol

\begin{tabular}{|c|c|c|}
\hline Usia & Frekuensi & Persentase (\%) \\
\hline 18-25 tahun & 12 & 50 \\
\hline 26-30 tahun & 12 & 50 \\
\hline Jumlah & 24 & 100 \\
\hline Mean & & 26,6 \\
\hline Min & & 22 \\
\hline Max & & 30 \\
\hline CI $95 \%$ & & $25,5-27,7$ \\
\hline
\end{tabular}

Kelompok kontrol lari 12 menit dengan program latihan rutin selama 6 minggu, baik pada umur 18-25 tahun maupun 26-30 tahun masing-masing berbagi jumlah yang sama yaitu 12 orang (50\%). Nilai rerata umur sampel adalah 26,6 tahun, umur termuda 
22 tahun umur tertua yaitu 30 tahun. dari hasil estimate interval dapat disimpulkan bahwa 95\% diyakini bahwa rerata rentang umur prajurit yaitu 25,5-27, 7 tahun.

\section{b. Analisis Bivariat}

\section{1). Uji Normalitas Data}

Sebelum dianalisis, untuk data karakteristik dilakukan uji normalitas dengan menggunakan tes Shapiro Wilk. Pada uji ini, data dikatakan berdistribusi normal apabila $\mathrm{p}$ value $>\alpha(0,05)$, sedangkan dikatakan tidak normal apabila $\mathrm{p}$ value $<\alpha(0,05)$.

Tabel 3 Hasil Shapiro Wilk pada Kelompok Eksperimen 1 dan 2

\begin{tabular}{lcccc}
\hline & \multicolumn{4}{c}{ P Value } \\
\cline { 2 - 5 } & $\begin{array}{c}\text { Kelompok } \\
\text { Eksperimen } \\
\end{array}$ & Keterangan & $\begin{array}{c}\text { Kelompok } \\
\text { Eksperime } \\
\mathrm{n} \mathrm{2}\end{array}$ & Keterangan \\
\hline Pre & 0,747 & Normal & 0,003 & $\begin{array}{c}\text { Tidak } \\
\text { Normal } \\
\text { Post }\end{array}$ \\
& 0,261 & Normal & 0,002 & $\begin{array}{c}\text { Tidak } \\
\text { Normal }\end{array}$ \\
\hline $\begin{array}{l}\text { Pre-Post dua } \\
\text { kelompok }\end{array}$ & & & & P Value $=0,004:$ Tidak Normal \\
\hline
\end{tabular}

Setelah dilakukan uji normalitas data didapatkan hasil skor intensitas nyeri pre dan post pada kelompok intervensi berdistribusi normal karena nilai signifikan shapiro wilk yang dihasilkan sebelum intervensi sebesar 0,747>0,05 dan sesudah intervensi $0,261>0,05$, sehingga selanjutnya dilakukan uji korelasi untuk mengetahui perbedaan rerata kebugaran responden pada kelompok intervensi menggunakan paired $t$ - test. Adapun uji normalitas data kebugaran pada kelompok kontrol didapatkan nilai shapiro wilk pretest sebesar $0,003<0,05$ dan postest sebesar $0,002<0,05$, dengan demikian uji korelasi untuk mengetahui perbedaan rerata kebugaran responden akan dilakukan dengan menggunakan uji wilcoxon. Sedangkan untuk mengetahui perbedaan rerata kebugaran pre test dan post test kelompok intervensi dan kontrol serta untuk mengetahui selisih pre test dan post test kebugaran menggunakan mann whitney test, dikarenakan nilai shapiro wilk pada uji normalitas data memperoleh nilai $0,004<0,05$ yang berartidistribusi data tidak normal.

\section{2) Uji Hipotesis}

Perbedaan Peningkatan Kebugaran Jasmani sebelum dan Sesudah Intervensi Pada Masing-Masing Kelompok

Tabel 4 Hasil Paired T-Test Terhadap Perbedaan Peningkatan Kebugaran Sebelum dan Sesudah Intervensi

\section{Pada Kelompok Eksperimen 1}




\begin{tabular}{lcccc}
\hline Variabel & Mean & SD & CI 95\% & p-value \\
\hline $\begin{array}{l}\text { Peningkatan kebugaran } \\
\text { sebelum dan sesudah }\end{array}$ & 44,13 & 6,244 & $\begin{array}{c}41,49- \\
46,76\end{array}$ & 0,002 \\
\hline $\begin{array}{l}\text { Sumber: Data Primer 2021 } \\
\text { number }\end{array}$
\end{tabular}

Pada kelompok eksperimen 1 (lari 12 menit dan core stability exercise), setelah diuji menggunakan uji statistik paired t-test dengan tingkat kepercayaan $95 \%$ didapatkan hasil $p$ value sebesar 0,002 .

Tabel 5 Hasil Wilcoxon Test Terhadap Perbedaan Peningkatan Kebugaran Sebelum dan Sesudah Intervensi

Pada Kelompok Eksperimen 2

\begin{tabular}{ccccc}
\hline Variabel & Mean & SD & CI 95\% & p-value \\
\hline $\begin{array}{c}\text { Peningkatan kebugaran } \\
\text { sebelum dan sesudah }\end{array}$ & 41,17 & 5,302 & $\begin{array}{r}38,98- \\
43,35\end{array}$ & 0,000 \\
\hline
\end{tabular}

Sumber: Data Primer 2021

Pada kelompok eksperimen (lari 12 menit), setelah diuji menggunakan uji statistik Wilcoxon test dengan tingkat kepercayaan 95\% didapatkan hasil p value sebesar 0,000.

3) Perbedaan Peningkatan Kebugaran Jasmani Antara Kelompok Eksperimen dan Kelompok kontrol

Pengujian hipotesis dengan menggunakan mann whitney $u$ test, dengan menguji selisih nilai peningkatan kebugaran jasmani sebelum dan sesudah intervensi pada kedua kelompok. Uji ini digunakan untuk melihat ada tidaknya perbedaan pengaruh yang bermakna pada selisih kebugaran jasmani sebelum dan dan sesudah intervensi diantara kedua kelompok. Hasil dikatakan menunjukkan perbedaan bermakna apabila $\mathrm{p}$ value < $\alpha(0,05)$, sedangkan dikatakan sama atau tidak ada perbedaan apabila $p$ value $>\alpha(0,05)$.

Tabel 6 Hasil Uji Mann-Whitney U Test Terhadap Selisih Peningkatan Kebugaran Jasmani Pada Kelompok 1 dan 2

\begin{tabular}{lc}
\hline & $\begin{array}{c}\text { Selisih Peningkatan Kebugaran } \\
\text { Jasmani Pada Kelompok 1 dan } \\
\text { 2 }\end{array}$ \\
\hline Mann-Whitney U & 138.500 \\
Wilcoxon W & 438.500 \\
Z & -3.110 \\
Asymp. Sig. (2-tailed) & .002 \\
\hline
\end{tabular}

Sumber : Data Primer 2021 
Pada Tabel 6 didapatkan hasil uji mann whitney u test bahwa p value 0,000 yang menunjukkan bahwa $\mathrm{p}$ value lebih kecil dari $\alpha(0,05)$.

\section{4) Uji Statistik sebelum intervensi}

Terdapat perbedaan Mean skor kesegaran jasmani A antara kelompok eksperimen (Mean= 40.33; $\mathrm{SD}=3.54)$ dan kelompok kontrol (Mean= 44.17; $\mathrm{SD}=6.72)$ sebelum intervensi, dan perbedaan tersebut secara statistik signifikan $(\mathrm{p}=0.017)$. Terdapat perbedaan selisih skor kesegaran jasmani sebelum dan sesudah intervensi antara kelompok eksperimen $(\mathrm{Mean}=4.38 ; \mathrm{SD}=1.41)$ dan kelompok kontrol $(\mathrm{Mean}=2,42$; $\mathrm{SD}=2.04)$ dan secara statistik signifikan $(\mathrm{p}<0.001)$, dengan effect size $=1.14$.

\section{Pembahasan}

Setelah menganalisa penelitian ini maka peneliti dapat menguraikannya dalam pembahasan Pengaruh Penambahan Core Stability Exercise terhadap Peningkatan Kebugaran Jasmani Prajurit Militer pada Kelompok Eksperimen

Berdasarkan hasil penelitian menunjukkan pada kelompok eksperimen (lari 12 menit dan core stability exercise), setelah diuji menggunakan uji statistik paired t-test dengan tingkat kepercayaan 95\% didapatkan hasil p value sebesar 0,002 Hasil ini menunjukkan bahwa terjadi peningkatan kebugaran jasmani yang dirasakan prajurit setelah diberikan penambahan core stability exercise, hal tersebut dapat terjadi karena saat beberapa faktor, salah satunya adalah kondisi kegiatan fisik. Hal tersebut sesuai dengan pendapat yang dikemukakan oleh Sinuraya \& Barus (2020) bahwa Kebugaran jasmani adalah kemampuan tubuh dalam menjalankan aktivitas fisik tanpa menimbulkan keletihan secara berlebihan. Kebugaran jasmani pada diri seseorang sangat dipengaruh oleh kondisi kegiatan fisik yang dilakukan. Kondisi fisik sangat penting dan faktor penting bagi seseorang untuk melakukan kegiatan sehari-hari. Sehingga kebugaran jasmani baik akan memberikan dampak dalam menjalankan kegiatan menjadi lebih segar dan tidak cepat lelah.

\section{Pengaruh Penambahan lari 12 menit terhadap Peningkatan Kebugaran Jasmani Prajurit Militer Pada Kelompok Kontrol}

Berdasarkan hasil penelitian menunjukkan bahwa Pada kelompok eksperimen 1 (lari 12 menit), setelah diuji menggunakan uji statistik Wilcoxon test dengan tingkat kepercayaan 95\% didapatkan hasil $\mathrm{p}$ value sebesar 0,000, yang berarti H0 ditolak, maka dapat disimpulkan bahwa terdapat perbedaan kebugaran jasmani pada prajurit militer kelompok kontrol sebelum dan setelah lari 12 menit.

Terdapat beberapa faktor yang dapat mempengaruhi tingkat kebugaran seorang prajurit militer, diantaranya adalah faktor tubuh. Hal ini didukung dengan pendapat yang dikemukakan oleh Santosa yang berpendapat Faktor yang mempengaruhi kesegaran jasmani, antara lain faktor postur tubuh, kerja faal tubuh, psikologi dan faktor penunjang. Selain itu kebugaran jasmani juga dapat dipengaruhi oleh jenis kelamin. Hal tersebut seperti dikemukakan oleh Sharkley (2016) yang berpendapat Kebugaran jasmani seseorang dipengaruhi oleh banyak faktor seperti keturunan (heriditer), jenis 
kelamin, usia, makanan/zat gizi, kebiasaan merokok, aktivitas fisik, status kesehatan (Sharkey et al., 2016).

Sebelum puber, tingkat kebugaran laki-laki dan perempuan tidak berbeda, namun setelah itu tingkat kebugaran laki-laki biasanya melebihi perempuan. Perbedaan ini dikarenakan perbedaan perkembangan dan fungsi hormone. Hormon Androgenik yang dimiliki laki-laki mempengaruhi perkembangan otot sehingga otot laki-laki lebih kuat dari perempuan. Kapasitas aerobik pada perempuan 15-25\% lebih rendah dari laki-laki. Salah satu alas an perbedaan tingkat kebugaran antara jenis kelamin dikarenakan perbedaan dalam jumlah hemoglobin dalam darah merah, dimana laki-laki mempunyai kadar $\mathrm{Hb}$ lebih tinggi dari kadar $\mathrm{Hb}$ pada perempuan. Jumlah hemoglobin berkaitan dengan VO2 dan daya tahan. Selain itu Wanita memiliki kelebihan lemak sebanyak $12.5 \%$ dibanding laki-laki (Jasmani et al., n.d.).

Pendapat tersebut sejalan dengan hasil penelitian yang dilakukan peneliti dimana berdasarkan analisa data hasil penelitian didapatkan hasil bahwa seluruh (100\%) responden pada kelomok kontrol maupun kelompok intervensi berjenis kelamin lakilaki. Hasil penelitian ini juga sejalan dengan hasil penelitian yang dilakukan Yusri (2020) yang menunjukkan hasil bahwa faktor jenis kelamin berpengaruh terhadap kebugaran jasmani.

\section{Perbedaan Pengaruh Penambahan Core Stability Exercise Terhadap Peningkatan Kebugaran Jasmani Pada Prajurit Militer Sebelum Dan Sesudah Eksperimen Antara Kelompok Intervensi Dengan Kelompok Kontrol}

Berdasarkan hasil penelitian menunjukkan bahwa perbedaan nilai rata-rata kebugaran jasmani pada prajurit militer setelah penambahan core stability exercise pada kelompok eksperimen 1 yaitu sebesar 47,79 sedangkan pada kelompok eksperimen 2 yaitu sebesar 42,17 dan setelah uji statistik dengan menggunakan mann whitney u test didapatkan $\mathrm{p}$ value $0,002<\alpha(0,05)$, yang berarti $\mathrm{H} 0$ ditolak. Maka dapat disimpulkan bahwa terdapat perbedaan pengaruh penambahan core stability exercise terhadap kebugaran jasmani setelah eksperimen pada prajurit militer antara kelompok eksperimen dengan kelompok kontrol.

Menurut analisa peneliti perbedaan peningkatan kebugaran jasmani pada prajurit militer yang diberikan intervensi penambahan core stability exercise dengan kebugaran yang dirasakan pada prajurit militer kelompok kontrol yang tidak mendapatkan intervensi, dapat dikarenakan pemberian core stability exercise memiliki efek yang baik terhadap kemampuan mengkontrol posisi gerakan batang badan melalui panggul dan kaki untuk memungkinkan produksi gerak yang optimal. Core stability yang baik berfungsi meningkatkan penampilan gerak untuk mencegah terjadinya cedera. Core stability merupakan salah satu faktor penting dalam postural tubuh.

Pendapat tersebut dipertegas oleh pendapat yang dikemukakan yang menjelaskan bahwa Otot-otot yang terlibat dalam core stability exercise adalah otot-otot kepala, leher, otot-otot belakang, otot-otot panggul, otot-otot perut, otot-otot hip. Dengan dilakukannya core stability exercise diharapkan dapat terjadi peningkatan kekuatan dari otot- otot yang bertanggung jawab untuk menjaga stabilisasi pada tulang belakang 
(trunk) dan dapat juga meningkatkan kekuatan dari otot-otot ekstremitas atas maupun bawah dalam bagian tubuh yang lemah. Latihan atau yang disebut sebagai exercise yang dapat menimbulkan perubahan pada otot-otot saat terjadinya kontraksi ketika melakukan core stability tersebut.

\section{Kesimpulan}

Terdapat perbedaan kebugaran jasmani pada prajurit militer kelompok intervensi sebelum dan sesudah penambahan core stability exercise dengan p-value 0,002. Terdapat perbedaan kebugaran jasmani pada prajurit militer kelompok kontrol sebelum dan setelah latihan lari 12 menit, dengan $\mathrm{p}$ value 0,000 . Terdapat perbedaan pengaruh penambahan core stability exercise terhadap kebugaran jasmani setelah eksperimen pada prajurit militer antara kelompok intervensi dengan kelompok kontrol., dengan $\mathrm{p}$ value $0,002<\alpha(0,05)$. 


\section{BIBLIOGRAFI}

Antonio Paoli, Quirico F Pacelli, Tatiana Moro, Giuseppe Marcolin, Marco Neri, Giuseppe Battaglia, Giuseppe Sergi, Francesco Bolzetta, Antonino Bianco. 2013. Effects of highintensity circuit training, low-intensity circuit training and endurance training on blood pressure and lipoproteins in middle-aged overweight men, Paoli et al. Lipids in Health and Disease 2013, 12:131, http://www.lipidworld.com/content/12/1/131 Google Scholar

Coulombe, B. J., Games, K. E., Neil, E. R., \& Eberman, L. E. (2017). Core stability exercise versus general exercise for chronic low back pain. Journal of Athletic Training, 52(1), 71-72. https://doi.org/10.4085/1062-6050-51.11.16 Google Scholar

Demirel, A., Oz, M., Özel, Y. A., Çetin, H., \& Ulger, O. (2019). Stabilization exercise versus yoga exercise in non-specific low back pain: Minimal clinically important difference in pain, disability, quality of life, performance. Complementary Therapies in Clinical Practice. doi:10.1016/j.ctcp.2019.02.004. Google Scholar

INDONESIA, S. N. R. (2004). Undang undang no 34 tahun 2004 tentang TNI. 1, 1-42. Google Scholar

Jasmani, S.-P., Rekreasi, K., \& Olahraga, F. I. (n.d.). Tingkat Kebugaran Jasmani Ekstrakurikuler Karate Di SMA NEGERI 2 SURABAYA Yogi Mahendra Prasetyo *, Bernard Djawa. Google Scholar

Miyake, Y., Kobayashi, R., Kelepecz, D., \& Nakajima, M. (2013). Core exercises elevate trunk stability to facilitate skilled motor behavior of the upper extremities. Journal of Bodywork and Movement Therapies, 17(2), 259- 265. Doi:10.1016/j.jbmt.2012.06.003. Google Scholar

Nugraha, P. D., Utama, M. B. R., S, A., \& Sulaiman, A. (2020). Survey Of Students Sport Activity During Covid-19 Pandemic. Jp.Jok (Jurnal Pendidikan Jasmani, Olahraga Dan Kesehatan), 4(1), 11-24. https://doi.org/10.33503/jp.jok.v4i1.805 Google Scholar

Penjakora, J., Bile, R. L., Tapo, Y. B. O., \& Desi, A. K. (2021). Pengembangan Model Latihan Kebugaran Jasmani Belajar Siswa Dalam Pembelajaran PJOK. 8(April), 71-80. Google Scholar

Perwira, J., Di, P., Mekanis, B., Jayasakti, P. I. K., Hanafi, M., Sitorus, H., \& J, T. G. (n.d.). Meningkatkan Pembinaan Karier Perwira Terhadap Pelaksanaan ... | Hanafi, Sitorus, Gabriel | 57. 57-74. Google Scholar

Pratama. (2020). Pengaruh Latihan Sirkuit Menggunakan Core Stability Static Exercise Terhadap Keseimbangan dan Daya Tahan Otot Perut. Universitas Nahdlatul Ulama Blitar, Indonesia.. Google Scholar

Sharkey, L. K. R., Edwards, T. A., \& O’Neill, A. J. (2016). ABC-F proteins mediate antibiotic resistance through ribosomal protection. MBio, 7(2), e01975-15. Google 
Feny Oktaviyani, Jenal Arifin

Scholar

Sinuraya, J. F., \& Barus, J. B. N. B. (2020). Tingkat Kebugaran Jasmani Mahasiswa Pendidikan Olahraga Tahun Akademik 2019/2020 Universitas Quality Berastagi. Kinestetik, 4(1), 23-32. https://doi.org/10.33369/jk.v4i1.10359 Google Scholar

Teofa, B. (2019). Effects of Dumbbell-Thera Band Exercise Towards the Arm Muscle Endurance and Archery Accuracy in Archery Athletes. Medikora, XVIII(2), 79-85. Google Scholar

Vanu Akuthota, Andrea Ferreiro, Tamara Moore, Michael Fredericson. 2008. Core Stability Exercise Principles. Cur. Sport Med. Rep., Vol. 7, No. 1, pp. 39-44. Google Scholar

First publication right:

Jurnal Syntax Fusion: Jurnal Nasional Indonesia

This article is licensed under:

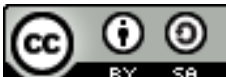

